\title{
Cross-border genetic testing
}

\author{
David Barton \\ From 5th European Conference on Rare Diseases (ECRD 2010) \\ Krakow, Poland. 13-15 May 2010
}

As genetic testing (GT) is now available for many rare disorders, no GT laboratory can be expert enough to provide every test. Samples are therefore sent between laboratories for testing, often across borders. Such cross-border testing raises some questions:

The 2003 OECD survey of 827 molecular GT laboratories in 18 countries found that $64 \%$ of laboratories had received samples from abroad. This percentage is likely to have increased in the intervening years, but no data are available.

Samples are usually sent abroad for specialist testing, but factors such as patents on genes and the centralisation of testing by private pathology companies also contribute to the traffic.

The main issue identified in the OECD report was the wide range of quality frameworks operating in different countries, leading to uncertainty about the quality of GT results obtained when samples are sent across borders. EuroGentest, with Orphanet, has established a quality assurance database of 1500 laboratories providing genetic tests in Europe. The database uniquely includes validated information on accreditation status and EQA participation for each laboratory and each test. For the public, this database facilitates an informed choice of laboratories; for genetic services, it allows the selection of partners for referral of tests based on their commitment to quality; for the laboratories, it valorises their efforts and investment in quality assurance.

While the In Vitro Diagnostic (IVD) Directive regulates the quality of diagnostic devices in the EU, most GT is exempt from the Directive as tests are manufactured and used in the same institution. EuroGentest has proposed that this exemption from CE-marking should be retained in the revised IVD Directive but it should be restricted to laboratories accredited to ISO 15189 or equivalent. This would protect the availability of rare

Correspondence: david.barton@olchc.ie

National Centre for Medical Genetics, Our Lady's Children's Hospital Crumlin, Dublin 12, Ireland

BioMed Central @ 2010 Barton; licensee BioMed Central Ltd disease testing, but ensure that it was carried out in laboratories with a robust quality system.

Published: 19 October 2010

doi:10.1186/1750-1172-5-S1-019

Cite this article as: Barton: Cross-border genetic testing . Orphanet Journal of Rare Diseases 2010 5(Suppl 1):019.

Submit your next manuscript to BioMed Central and take full advantage of:

- Convenient online submission

- Thorough peer review

- No space constraints or color figure charges

- Immediate publication on acceptance

- Inclusion in PubMed, CAS, Scopus and Google Scholar

- Research which is freely available for redistribution

Submit your manuscript at www.biomedcentral.com/submit 